\title{
Poverty's Deconstruction: Beyond the Visible
}

\author{
Sumon Kumar Bhaumik, Ira N. Gang and Myeong-Su Yun
}

\begin{abstract}
In contrast to his contribution to other areas, Shubhashis Gangopadhyay's contributions to our understanding of poverty are often thought of as indirect consequences of the main themes of his work. Yet in more than 15 published papers Gangopadhyay directly takes on poverty, including its estimate and understanding its sources. Our contribution honours Gangopadhyay's work in this area by outlining an approach useful in deconstructing the changes and differences in the likelihood of poverty incidence. We highlight how far it can take us, and how it still leaves us far short of understanding much of what drives poverty.
\end{abstract}

\section{Introduction}

By some measures, global poverty, based on the $\$ 1.90$-a-day threshold, has declined significantly over the past two decades. Largely, this decline has been driven by a sharp fall in poverty incidence in East Asia and South Asia, home of two populous and rapidly growing countries, namely, China and India. In South Asia, for example, poverty incidence declined from 44.1 percent of population in 1990 to 15.1 percent in 2013. However, as of 2013, South Asia continued to be home to 256 million poor people. In some other parts of the world, success with poverty reduction has been less spectacular. For example, in Sub-Saharan Africa both the headcount poverty rate-proportion of the population that is poor - and the number of people below the poverty line remain stubbornly high at 41 percent and 388 million, respectively. Given that worldwide more than 750 million people live below the very modest international poverty line, poverty continues to be a relevant economic, social and political issue.

Not surprisingly, economists and policymakers continue to be interested in the correlates of poverty. Using 2013 data, the World Bank (2016) finds "the global poor are predominantly rural, young, poorly educated, mostly employed in the agricultural sector, and live in larger households with more children. Indeed, 80 percent of the worldwide poor live in rural areas; 64 percent work in agriculture; 44 percent are 14 years old or younger; and 39 percent have no formal education at all." Similarly, Gangopadhyay's own research on poverty in the Indian context has examined the correlation between poverty incidence and gender, socio-economic characteristics (e.g., caste, human capital) and household location (e.g., urban vs rural) (Dubey et al., 2001; Gangopadhyay and Wadhwa, 2004a, and 2004b). How 
informative are these empirical exercises about poverty? Do they obscure as much or, indeed, more than they reveal? These are questions that Gangopadhyay has pondered as a development economist. We honour him in this chapter by exploring them through both empirical and conceptual prisms.

As such, while from a policymaking perspective it is deemed important to have a better understanding of how endowments such as education and assets can affect income and, hence, the likelihood of being in poverty, political economy requires that policymakers are equally attentive to variations in poverty incidence across socio-demographic cohorts that can be differentiated by characteristics such as gender, ethnicity, caste (where applicable) and religion. It is well understood in the labour economics literature that differences in individual income are influenced by not only differences in endowments such as education and experience, ${ }^{1}$ but also by the differences in the returns to these endowments. By the same token, the difference in poverty incidence between two socio-demographic groups is influenced by differences in the endowments of education, assets etc. between these groups, as well by differences in the returns to these endowments.

From a methodological standpoint, this involves decomposing, for example, differences in per capita (or per adult equivalent) consumption, or indeed the headcount poverty rate, of households who differ in some identifiable and hopefully exogenous way, e.g., caste or ethnicity (e.g., Bhaumik et al., 2006b; Gang et al., 2008). As such, our exercise addresses the empirical question as to how much the gap in poverty incidence or per adult equivalent expenditure of the groups that are being compared would shrink if they have, on average, similar endowments and capabilities, and returns to these endowments and capabilities. While this is an attractive and useful exercise, this empirical approach is dogged by a major problem: the model specifications that are used to explain variations in income across households - therefore, implicitly, the likelihood of being in poverty - may not explain a significant proportion of the aforementioned variation. Correspondingly, the decomposition approach mentioned above fails to explain a significant proportion of the differences in income or poverty incidence across socio-demographic groups. In their analysis of income or earnings differences between Serb and Albanian households in Kosovo, for example, Bhaumik et al. (2006b) conclude that:

Our analysis suggests that, in keeping with the popular wisdom about Kosovo's political economy, the characteristics and coefficients effects of economically meaningful variables largely favor Serb households. The lower incidence of poverty

${ }^{1}$ For a discussion of the relationship between individual endowments and income or earnings, see Heckman et al. (2006). 
among Albanian households is due partly to private transfers received by Albanian households, possibly from children living abroad. However, much of the difference in the average living standards between these two groups is explained by noneconomic factors as captured by the constant terms in the underlying regression estimations.

In other words, policymakers aiming to alleviate poverty have to be attentive not only to individual and household endowments such as education and assets that can be affected by appropriate policies, they may need to take into account noneconomic factors that are either unobserved or are difficult to quantify. This, in turn, has implications for viewing poverty not through the lens of endowments alone but through the lens of capability. As argued by Sen (2005), "[t]he capability approach can help to identify the possibility that two persons can have very different substantial opportunities even when they have exactly the same sets of means".

In this chapter, we first demonstrate the usefulness as well as the limitations of a decomposition-based approach to examining differences in poverty incidence across socio-demographic groups. We use the specific case of difference in poverty incidence between Serbs and Albanians in Kosovo for this demonstration. We then draw on related literature to discuss why endowments and returns thereof may not, on their own, explain differences in income/consumption and hence poverty incidence. Specifically, we discuss how norms and (even when norms are favourable) the path dependent stock of social capital influence individuals' (and hence households') capability, and hence their ability to translate endowments and capabilities into a commensurate level of income. This has significant implications for the research on poverty that is a significant part of Gangopadhyay's distinguished research portfolio.

\section{Explaining poverty incidence within and between socio-demographic groups}

In the development literature, there is a long tradition of identifying the correlates of poverty using a modelling framework within which a binary indicator of being in poverty, based on an exogenously given poverty line, is regressed on household characteristics such as demographic composition of households (e.g., age distribution, dependency ratios), educational qualifications of working age adults, asset ownership and location (e.g., urban vs. rural, or region of the country) (e.g., Bhaumik et al., 2006a). In many cases, the age, gender, education and other relevant characteristics of the household head is used instead (e.g., Rodriguez and Smith, 1994; Grootaert and Braithwaite, 1998). The model can be summarised as

$$
Y=F(X \beta)
$$


where $Y$ is the binary indicator of poverty, $X$ is a vector of household characteristics, $\beta$ are regression estimates, and $F($.) is any once-differentiable function mapping a linear combination of $X(X \beta)$ to $Y$.

Equation (1) is estimated using probit or logit regressions, as Gangopadhyay himself had done in his analysis of poverty in India (Dubey et al., 2001):

We model the probability of being poor as a function of three variables: town or city size, education, and household size. .... The dependent variable is a binary zeroone variable, POVU, which takes on a value of 1 if the household's per capita consumption expenditure is below the poverty line, zero otherwise.

The regression estimates in turn, can be used to compute the marginal effect of the relevant explanatory variables (i.e., household or household head's characteristics) on the likelihood of being in poverty (Fofack, 2002). ${ }^{2}$

The regression-based analysis of poverty can be leveraged to develop a better understanding of the factors influencing differences in poverty incidence between two socio-demographic groups, generally those that are differentiated on the basis of exogenous characteristics such as race, ethnicity, caste and religion. This follows, once again, from the labour economics literature that has extensively examined the drivers of wage/earnings differences between socio-demographic groups by decomposing this difference into different components (e.g., Neuman and Silber, 1996; Bhaumik and Chakrabarty, 2009). The decomposition method that was initially developed for linear regression models (Blinder, 1973; Oaxaca, 1973) has since been extended to nonlinear models. Once equation (1) has been estimated for two different groups $A$ and $B$, the mean difference in $Y$ between the groups can be decomposed as:

$$
\bar{Y}_{A}-\bar{Y} B=\left[\overline{F\left(X_{A} \beta_{A}\right)}-\overline{F\left(X_{B} \beta_{A}\right)}\right]+\left[\overline{F\left(X_{B} \beta_{A}\right)}-\overline{F\left(X_{B} \beta_{B}\right)}\right]
$$

where, in the context of poverty incidence, the first component refers to the part of the differential owing to differences in household endowments (characteristics effect), and the second component refers to that part of the differential attributable to differences in coefficients (coefficients effect).

2 A variation is using panel data models with binary indicators of poverty. These are estimated using random effects probit/logit regressions, and can be modified to accommodate a dynamic framework within which the likelihood of being in poverty in period $\mathrm{t}$ is influenced by whether or not the household was in poverty in period $t-1$ (Biewen 2009). 
It has, however, been argued that a probit model does not, by its very nature, fully utilise the rich information of the continuous variable, namely, income or consumption, that underpins the binary indictor of poverty. The World Bank (Klugman, 2002) proposes that poverty incidence can be computed by using $R$, the ratio of per capita income or expenditure $(Y)$ to the poverty line $(Z)$, i.e., $R=Y / Z$. Next, one estimates the regression equation, $\ln R=X \beta+e$, where $R, X$, and $\beta$ are, respectively, an $N \times 1$ vector, an $N \times K$ matrix of independent variables (generally household characteristics), a $K \times 1$ vector of estimated coefficients, and $e$ is the error term. Computing $\operatorname{Pr}(\log R<0)=\operatorname{Pr}(\log Y<\log Z)$ provide the probability of being poor. In practice, this probability is usually calculated using the standard normal distribution, i.e., $\operatorname{Pr}(e<-X \beta)=\Phi(X \widetilde{\beta})$, where $\widetilde{\beta}=-\beta / \sigma$ and $\sigma$ is the error term's standard deviation $(e)$.

Once poverty incidence is measured using the transformed regression coefficients, one can answer the "what if" questions by simulating the impact of various policies on poverty incidence - e.g., what if a disadvantaged sociodemographic group is provided government support to obtain educational qualifications that is similar to a better off socio-demographic group. While these simulation methods are useful, they have an important conceptual limitation. The aforementioned simulation exercise gauges the impact of changing the values of few policy variables while keeping others constant, and one has to repeat the process to obtain a full picture of how policy changes can affect inter-group differences in poverty incidence. However, successive substitution based simulation is prone to a well-known path dependency problem, whereby sequential substitution provides different pictures depending on the order of substitution (see Ham et al. 1998).

Bhaumik et al. (2006c) demonstrate that World Bank's approach of computing poverty incidence using regression estimates can be seamlessly synthesized with the Blinder-Oaxaca type decomposition method proposed by Yun (2004). Their methodology overcomes the path-dependency problem of the simulation method, and provides the effect of not only changes in household characteristics and endowments, but also changes in their coefficients. Furthermore, they propose a significance test to examine whether the characteristics and coefficients effects thus computed contribute significantly to the observed difference in poverty incidence. In the following section, we use the algorithm discussed in Bhaumik et al. (2006c) to decompose incidence of poverty among ethnic Albanians and ethnic Serbs in postcivil war Kosovo.

\section{An application: Serbs and Albanians in Kosovo}

The conflict between ethnic Serbs and ethnic Albanians in Kosovo, in the aftermath of the disintegration of the former state of Yugoslavia, is well documented. Scholars 
have traced the conflict between these two ethnic groups at least as far back as 1948 (Artisien, 1984), and some have even argued that it can traced back to 1912, when Serbia annexed Kosovo from the Ottomans and ethnic Albanians suffered huge casualties during the war (see Gallagher 2005; Chapter 2 and references therein). During World War II, Yugoslavia was occupied by the Axis powers, and while Albanians were wary of joining forces with the occupying powers, they were also reluctant to join the communist-led Partisans. When the state of Yugoslavia was created in the dying days of the war, the Tito-led communist government in power opposed secession of ethnic Albanians from the newly-formed state. In 1944-45, a rebellion against the Yugoslav authorities was organised in the Drenica region, and it is believed that a large number of Albanians succumbed to Tito's military response.

The intensity of the hostility between the ethnic groups waned over time, at least in theory, especially after the Yugoslav government granted the autonomous province of Kosovo two major rights, namely, its borders could not be changed without the consent of the people, and the province had the same rights as the other republics of the Yugoslav Federation. However, as documented by Bhaumik et al. (2009), ethnic tensions returned to the province after Tito's death and peaked in 1989, when Milosevic started limiting the province's autonomy. In 1990, the Albanian secessionists declared independence. Even as the Milosevic government cracked down on Albanian institutions in Kosovo, and while the international community attempted to broker a deal between the warring ethnic factions in former Yugoslavia, Kosovo was not brought into the ambit of negotiations with Serbia, even at the Dayton Agreement of 1995. This neglect empowered militants within the political spectrum of the Kosovar Albanians, at the very least hastening and/or intensifying the conflict between the Serbs and Albanians in Kosovo during the second half of the 1990s. Bhaumik et al. (2009) note that:

The marginalisation of Kosovo and the [Democratic] League [of Kosovo] undercut [Ibrahim] Rugova's authority, and the militant Kosovo Liberation Army became the standard bearer for the Kosovar Albanians during the second half of the 1990s. The resultant more elevated form of conflict lasted until 1999, with NATO intervening militarily to force Milosevic to withdraw Serb forces from Kosovo.

Following the civil war between the Serbs and Albanians, in which NATO intervened, Kosovo was declared a UN protectorate in 1999.

Table 1 Determinants of Ratio of Per Capita Expenditure to Poverty Line (ML estimation)

\begin{tabular}{lllll}
\hline & Albanians & \multicolumn{3}{l}{ Serbs } \\
\hline & Estimate & S.E. & Estimate & S.E. \\
\hline
\end{tabular}




\begin{tabular}{|c|c|c|c|c|}
\hline Constant & $-0.33 * * *$ & $(0.09)$ & $-1.10^{* * *}$ & $(0.21)$ \\
\hline \multicolumn{5}{|l|}{ Demographic characteristics of households } \\
\hline Proportion aged 15 or below & $-0.58 * * *$ & $(0.06)$ & -0.17 & $(0.12)$ \\
\hline Proportion aged above 65 & -0.10 & $(0.11)$ & -0.06 & $(0.13)$ \\
\hline Proportion of adults who are male & 0.04 & $(0.09)$ & 0.23 & $(0.16)$ \\
\hline Households with male head & -0.06 & $(0.05)$ & 0.06 & $(0.09)$ \\
\hline \multicolumn{5}{|l|}{ Education } \\
\hline Proportion of adults with primary education & $0.18 * *$ & $(0.08)$ & 0.31 & $(0.19)$ \\
\hline Proportion of adults with secondary education & $0.58 * * *$ & $(0.08)$ & $0.92 * * *$ & $(0.20)$ \\
\hline Proportion of adults with vocational training & $0.52 * * *$ & $(0.10)$ & $0.91 * * *$ & $(0.23)$ \\
\hline Proportion of adults with tertiary education & $0.75 * * *$ & $(0.10)$ & $1.46^{* * *}$ & $(0.21)$ \\
\hline \multicolumn{5}{|l|}{ Labor market characteristics } \\
\hline Proportion of working adults & $0.45^{* * *}$ & $(0.06)$ & $0.22 * *$ & $(0.11)$ \\
\hline $\begin{array}{l}\text { Proportion of households with members } \\
\text { working in family farms \& businesses }\end{array}$ & -0.00 & $(0.07)$ & -0.04 & $(0.11)$ \\
\hline \multicolumn{5}{|l|}{ Wealth/Assets } \\
\hline Acreage of land household owns $(000)$ & 0.17 & $(0.15)$ & 0.01 & $(0.01)$ \\
\hline Value of animals household owns (000 DM) & 0.03 & $(0.02)$ & 0.04 & $(0.03)$ \\
\hline \multicolumn{5}{|l|}{ Transfers } \\
\hline $\begin{array}{l}\text { Households at least one of whose members } \\
\text { has a disability card }\end{array}$ & 0.02 & $(0.04)$ & -0.10 & $(0.07)$ \\
\hline $\begin{array}{l}\text { Household at least one of whose members } \\
\text { receive private transfers }\end{array}$ & $0.09^{* * *}$ & $(0.02)$ & $0.33 * * *$ & $(0.11)$ \\
\hline \multicolumn{5}{|l|}{ Geographic Characteristics } \\
\hline Urban households & 0.05 & $(0.03)$ & 0.06 & $(0.06)$ \\
\hline Standard deviation of error term $(\sigma)$ & $0.46^{* * *}$ & $(0.01)$ & $0.46^{* * *}$ & $(0.03)$ \\
\hline Log-likelihood $(L)$ & \multicolumn{2}{|c|}{-150785.98} & \multicolumn{2}{|c|}{-19300.24} \\
\hline Constrained Log-likelihood $(L O)$ & \multicolumn{2}{|c|}{-180607.61} & \multicolumn{2}{|c|}{-25300.89} \\
\hline Number of households & \multicolumn{2}{|c|}{2101} & \multicolumn{2}{|c|}{41} \\
\hline
\end{tabular}

Note: $*, * *$ and $* * *$ indicate significance at the $10 \%, 5 \%$ and $1 \%$ levels, respectively. Weights are used in estimation. Standard errors which are robust to mis-specification are reported. Constrained log-likelihood is calculated only when constant and standard deviation of error term are estimated. Likelihood ratio test, $2 *(\mathrm{~L}-\mathrm{L} 0)$, rejects the null hypothesis that coefficients except for the constant are zero for both Serbs and Albanians. Source: Bhaumik et al. (2006c).

Unsurprisingly, economic hardship accompanied the conflict and indeed outlasted it. Data from the Living Standard Measurement Survey (LSMS), conducted by the World Bank in 2000, indicated that the headcount poverty rate was 46 percent among ethnic Albanians and 57 percent among ethnic Serbs. Correspondingly, per capita expenditure for Albanian and Serb households was DM 128.98 and DM 111.23, respectively. Bhaumik et al. (2006a) demonstrate that the educational status of adult household members and private transfers were the most important correlates of poverty. The likelihood of being in poverty, for both Albanian and Serb households, declined with increasing proportions of adult household members with secondary, vocational and tertiary education. This 
likelihood was also reduced if at least one household member reported receiving private inter-vivos transfers. These results are not surprising, and are entirely consistent with the wider empirical literature on poverty. The same insights are provided by the adoption of the World Bank's approach in which the dependent variable is the ratio of household-level per capita expenditure to the poverty line, instead of being a binary indicator of poverty status (Table 1).

Table 2 Decomposing Difference in Poverty Rates of $10.56 \%$ between Serbs and Albanians using Estimates of Per Capita Expenditure Regression Equations.

\begin{tabular}{|c|c|c|c|c|}
\hline & \multicolumn{2}{|c|}{$\begin{array}{l}\text { Characteristics } \\
\text { Effect }\end{array}$} & \multicolumn{2}{|c|}{$\begin{array}{l}\text { Coefficients } \\
\text { Effect }\end{array}$} \\
\hline & Estimate & Share & Estimate & Share \\
\hline Aggregate Effect & -0.035 & -33.55 & $0.141 * * *$ & 133.55 \\
\hline Aggregate Effect Without Constants & -0.035 & -33.55 & $-0.429 * *$ & -405.66 \\
\hline Constant & & & $0.570 * * *$ & 539.21 \\
\hline Demographic characteristics of households & -0.016 & -15.04 & $-0.244 * *$ & -231.24 \\
\hline Proportion aged 15 or below & $-0.021 *$ & -19.52 & $-0.095 * * *$ & -90.19 \\
\hline Proportion aged above 65 & 0.003 & 2.90 & -0.001 & -0.97 \\
\hline Proportion of adults who are male & -0.001 & -1.33 & -0.068 & -64.11 \\
\hline Proportion with male head & 0.003 & 2.92 & -0.080 & -75.96 \\
\hline Education & $-0.113 * * *$ & -106.66 & -0.191 & -180.66 \\
\hline Proportion of adults with primary education & $0.034^{*}$ & 32.64 & -0.044 & -41.81 \\
\hline Proportion of adults with secondary education & $-0.165 * * *$ & -155.94 & $-0.076^{*}$ & -72.17 \\
\hline Proportion of adults with vocational training & $0.006 * * *$ & 5.33 & -0.024 & -22.42 \\
\hline Proportion of adults with tertiary education & $0.012 * * *$ & 11.32 & $-0.047 * * *$ & -44.25 \\
\hline Labor market characteristics & $-0.008 *$ & -7.64 & $0.074 * *$ & 70.41 \\
\hline Proportion of working adults & $-0.010^{*}$ & -9.67 & $0.067 *$ & 63.30 \\
\hline $\begin{array}{l}\text { Proportion of households with members } \\
\text { working in family farms \& businesses }\end{array}$ & 0.002 & 2.02 & 0.008 & 7.11 \\
\hline Wealth/Assets & 0.003 & 2.46 & 0.003 & 2.88 \\
\hline Acreage of land household owns (000) & -0.000 & -0.36 & 0.008 & 7.39 \\
\hline Value of animals household owns (000 DM) & 0.003 & 2.82 & -0.005 & -4.51 \\
\hline Transfers & $0.106^{* *}$ & 100.00 & $-0.068^{*}$ & -64.28 \\
\hline $\begin{array}{l}\text { Proportion of households at least one of whose } \\
\text { members has a disability card }\end{array}$ & -0.000 & -0.03 & 0.009 & 8.65 \\
\hline $\begin{array}{l}\text { Proportion of household at least one of whose } \\
\text { members receive private transfers }\end{array}$ & $0.106^{* *}$ & 100.03 & $-0.077 * *$ & -72.92 \\
\hline \multicolumn{5}{|l|}{ Geographic Characteristics } \\
\hline Urban households & -0.007 & -6.67 & -0.003 & -2.77 \\
\hline
\end{tabular}

Notes: Share is the ratio of the contribution of each factor to the "predicted" overall difference in poverty rate $(10.56 \%)$ between Serbs (55.98\%) and Albanians (45.41\%), in percentage terms. The observed overall difference in poverty rate are $11.87 \%$ between Serbs (57.38\%) and Albanians (45.52\%). The predicted poverty rate is computed using estimates from the per capita expenditure regression. ${ }^{*}, * *$ and $* * *$ indicate significance at the $10 \%, 5 \%$ and $1 \%$ levels, respectively. Source: Bhaumik et al. (2006c). 
Indeed, given the post-war political history of Kosovo, in which the ethnic Serbs were dominant, the most interesting and counter-intuitive observation was the noticeably higher headcount poverty rate among Serb households than among Albanian households. In large measure, this outcome may have been driven by private transfers, rather than by endowment of human and physical capital. On average, Serb households had more educated adults than Albanian households, but the incidence of private transfers was much higher for the latter than for the former (Bhaumik et al., 2006a). In order to better understand this counter-intuitive observation, Bhaumik et al. (2006c) decompose the observed 10.56 percentage point difference in the headcount poverty rates of Albanian and Serb households into characteristics and coefficient effects. They find that -33.55 percent of the aforementioned gap is explained by the characteristics effect, and 133.55 percent of it is explained by the coefficients effect (Table 2).

In other words, Serbs would be worse off if the differences between their characteristics and those of the Albanian households disappear, and Serbs would be better off if there is no difference in the poverty mitigating effectiveness of those characteristics between the Serbian and Albanian households. Remember that these "characteristics" are the endowments such as human and physical capital, the effectiveness of these characteristics in mitigating poverty, therefore, depends on the nature and extent of market (or entitlement) failure in the relevant market. In other words, the headline decomposition results suggest that Serb households may have experienced greater entitlement failure in Kosovo than Albanian households. When we look at detailed decompositions, however, it becomes clear that the main reason why Serbs have higher poverty incidence is due to the coefficients effect of the constant term. Even though Serbs have better poverty lowering characteristics, and enjoy stronger poverty mitigating effects of these characteristics relative to Albanians, there is huge baseline gap in poverty incidence between the two ethnic groups, captured by the coefficients effect of the constant term.

The dominance of the constant term, which is difficult to interpret and which is unrelated to tangible and intangible endowments of households, brings to the fore the difficulty of the empirics of poverty analysis discussed earlier in this chapter. An early indication of this problem can be found in simple probit analysis of poverty itself. For example, despite using a conceptually complete specification that includes the labour power of households (age distribution), and other tangible and intangible endowments such as human and physical capital, and location, the probit equations reported by Bhaumik et al. (2006a) had McFadden's R-square statistic of 0.136 for the sample of Albanian households and that of 0.193 for the sample of Serb 
households. This takes us back to the issue about the low explanatory power of endowments that attracts the attention of policymakers, ${ }^{3}$ and in the next section we discuss possible reasons for this observation and their implications for the policymaking process.

\section{Poverty and capability}

At the risk of sweeping generalisation, and as implied in discussions earlier in this chapter, the economic approach to poverty can be summarised as follows: Households (and their members) have tangible and intangible endowments; for most people/households, this endowment exists in the form of labour power. Households and their members attempt to translate the ownership of these assets to income flows to mitigate household expenses and, on some occasions, accumulate financial and non-financial assets. When the income flow falls below $\$ 1.90$ per adult equivalent, per day, a household is deemed to be in poverty. The policy response to poverty incidence is, in part, to increase the endowments of poor households, e.g., through education provision and land redistribution, and, in part, by ensuring that vulnerable socio-demographic groups are able to translate their endowments into income flows, e.g., through labour policy interventions such as employment quotas or positive discrimination. Similarly, where there are noticeable differences in incidence (and other poverty measures of) between two socio-demographic groups, governments intervene through measures such as employment reservations and positive discrimination that favour the group(s) with higher poverty incidence. On average, there is much greater emphasis in policy circles on enhancing endowments than on other poverty mitigating measures. Gangopadhyay's own research, for example, has emphasised the importance of wealth redistribution in pulling households out of poverty traps (Dimova et al., 2015).

The capability approach to poverty sharpens focus on the functionings of individuals. In the words of Sen (1993):

Functionings represent parts of the state of a person - in particular, the various things that he or she manages to do or be in leading a life. The capability of a person

3 This problem has also been observed by researchers who examine related issues such as wealth gaps between ethnic groups. For example, Emmons and Ricketts (2017) found that "the share of wealth gaps that can be explained by observables falls below one fifth for Blacks and Hispanics and to about three quarters for Asians. In other words, a structural determinants framework suggests the vast majority of the Black-White and Hispanic-White wealth gaps may lie beyond the scope of individual actions or marginal policy changes directed at educational attainment, family structure, financial decision-making, or even wealth redistribution. Instead, the gaps appear to be deeply rooted in unobservable factors that may include discrimination or other long-lasting disadvantages." 
reflects the alternative combination of functioning the person can achieve, and from which he or she can choose one collection.

This has immediate implications for poverty. If the choices that a person can make, and indeed would make when operating without any constraints, are infeasible for any reason, her capability of translating her endowments into income flows can be significantly reduced. For example, if a farmer cannot use water from a well because he is of a low caste, that may affect his ability to have the desirable level of productivity and, hence, income. Similarly, if a woman cannot take up a well-paying job that is commensurate with her education because either social norms or deteriorating law and order prevents her from working at specific times of the day and/or in specific work environments, her capability of translating her human capital into income flow is equally affected. ${ }^{4}$ Indeed, the capability approach goes further than income alone, and takes into consideration issues such as (ability to) "appear in public without shame" and "taking part in the life of the community" (Volkert, 2006). However, given the emphasis of the poverty line on an incomeexpenditure threshold, in this chapter, we shall stick to the income aspect of capability.

Recent research has highlighted the relevance and importance of the capability as opposed to endowment-focused - approach to poverty. For example, in the context of Malawi, Bhaumik et al. (2016) examine gender differences in the impact of land ownership on participation in high value agriculture which is desirable from an income flow perspective. They find that even within matrilineal societies in Malawi the likelihood of cultivating high value crops increases with the amount of land owned by men within these households. They conclude that:

...de jure female ownership of assets may not be a panacea in developing economy contexts; household interests may be better served by male ownership of these assets, either because men in these contexts have better access to complementary resources that enable them to deploy the assets in ways that enhance returns to them, or because uncertainty about property rights induce women to take less risk or under-invest in these assets.

It is easy to see how this line of functioning by women can be inhibited by factors such as social norms that dictate the ability of women to participate in social

\footnotetext{
${ }^{4}$ As Sen (2005) argues, capability can also be affected if these people are forced to act in a way in which they would have acted anyhow, e.g., if the woman is forced to work. However, in the context of poverty, more often than not, the problem lies with the inability of people to productively market their endowments, and thereby translate these endowments into income flows.
} 
and economic institutions that facilitate access to complementary resources such as capital that is essential for participation in high value agriculture. By extension, assuming that it is rational for women to invest in high value crops purely from an income-economic perspective, it is also easy to see how loss of capability can affect a woman's ability to translate endowments into income flow, an observation that is consistent with the evidence of higher poverty incidence among women-headed households in developing countries.

A corollary of this line of argument is that policies aimed at reducing or eradicating poverty should not only focus on human agency - "the way in which household livelihood strategies are built around protecting, substituting, increasing and using assets to produce security and achieve other goals" (Hulme and Shepherd, 2003) - but also on the capacity of the poor for social action. As argued by Wood (2003):

Not all types of poor people can effectively act for themselves, even if supported externally to do so. Thus we have idiosyncratic, chronic poverty comprising varied but extreme incapacity for social action: the elderly; orphans (thus perhaps only transitory); widows in patrilineal and patriarchal societies; people with disability (physical as well as learning difficulties); people with long-term illness and morbidity. To these groups, we might add outgroups of various kinds whose exclusion reduces their capacity for social action: migrants; ethnic minorities; minority religious sects within dominant cultures. Thus people may have reduced agency either for individual or for broader ascriptive reasons. In the absence of other help, such people really do have to rely upon responsible and accountable governments, prepared to uphold a broad concept of human rights and prepared to offer meaningful social protection via affirmative action and welfare. They are not well placed, however, to bring about such responsibility in government, and have to rely upon the agency of others, who are capable of social action to this end.

In other words, while poverty may manifest itself through the endowment of tangible and intangible assets and, eventually, through income and expenditure, the state of poverty involves absence of control over one's own choices. This could, in turn, result in an internalisation of the reduction in choices and/or commitment to institutions and patrons that can provide greater security in the short term at the expense of greater vulnerability in the long run. In contexts where capabilities of specific socio-demographic groups are severely constrained, policies aimed at providing individuals and households with an opportunity to augment and effectively market their endowments alone are unlikely to alleviate poverty to a significant extent. By extension, focusing on endowment differences between two socio-demographic groups may not effectively reduce differences in poverty incidence between them. 


\section{Concluding remarks}

One of Gangopadhyay's many contributions as a development economist is in the field of poverty, in particular, his extensive empirical investigation of trends and patterns of poverty in India during the 1990s. This study honours his contribution in this area by reflecting on the advantages and inadequacies of empirical approaches to an examination of poverty, using an analysis of differences in poverty incidence among Albanian and Serb households in Kosovo, in the immediate aftermath of the civil war of the 1990s. In particular, it highlights the aspects of capability that empirical approaches cannot adequately capture, and how, therefore, robust empirical analysis and an understanding of the context, norms, power equations among castes, ethnic groups, religious groups, genders etc. can (and should) supplement each other in the context of policymaking for poverty alleviation, or reduction of disparities in poverty levels among socio-demographic groups. The key lies in being mindful about the unobservable, and sometimes deep-rooted, frictions that impair the freedom of individuals and households to make choices that are potentially beneficial for them but may be unavailable to them. The solution to the phenomenon of poverty, and inter-group differences in poverty, may, therefore, be as much in the domain of social sciences such as politics, sociology and anthropology, as in the domain of economics. As an erstwhile advisor to the Government of India, Gangopadhyay would almost certainly see the merit of this broad-tent approach to analysis of poverty.

\section{References}

Bhaumik, S.K., and M. Chakrabarty. 2009. Is education the panacea for economic deprivation of Muslims? Evidence from wage earners in India, 1987-2005. Journal of Asian Economics, 20(2): 137-149.

Bhaumik, S.K., Dimova, R., and I.N. Gang. 2016. Is women's ownership of land a panacea in developing countries? Evidence from land-owning farm households in Malawi. Journal of Development Studies, 52(2): 242-253.

Bhaumik, S.K., Gang, I.N., and M-S. Yun. 2006a. A note on poverty in Kosovo. Journal of International Development, 18(8): 1177-1187.

Bhaumik, S.K., Gang, I.N., and M-S. Yun. 2006b. Ethnic conflict and economic disparity: Serbians and Albanians in Kosovo. Journal of Comparative Economics, 34(4): 754-773.

Bhaumik, S.K., Gang, I.N., and M-S. Yun. 2006c. A note on decomposing differences in poverty incidence using regression estimates: Algorithm and example. IZA Discussion Paper No. 2262, Bonn: IZA - Institute for Labor Economics.

Bhaumik, S.K., Gang, I.N., and M-S. Yun. 2009. Rationality as a barrier to peace: Microevidence from Kosovo. Comparative Economic Studies, 51(2): 242-264.

Biewen, M. 2009. Measuring state dependence in individual poverty histories when there is feedback to employment status and household composition, Journal of Applied Econometrics, 24(7): 1095-1116. 
Blinder, A.S. 1973. Wage discrimination: Reduced form and structural estimates. Journal of Human Resources, 8(4): 436-455.

Dimova, R., Gangopadhyay, S., Michaelowa, K., and A. Weber. 2015. Off-farm labor supply and correlated shocks: New theoretical insights and evidence from Malawi. Economic Development and Cultural Change, 63(2): 361-391.

Dubey, A., Gangopadhyay, S., and W. Wadhwa. 2001. Occupational structure and incidence of poverty in Indian towns of different sizes. Review of Development Economics, 5(1): 49-59.

Emmons, W.R., and LR. Ricketts. 2017. College is not enough: Higher education does not eliminate racial and ethnic wealth gaps. Working paper no. 17-12, Opportunity \& Inclusive Growth Institute, Federal Reserve Bank of Minneapolis.

Fofack, H. 2002. The nature and dynamics of poverty determinants in Burkina Faso in the 1990. Policy Research Working Paper No. 2847, Washington, DC: The World Bank.

Gang, I.N., Sen, K., and M-S. Yun. 2008. Poverty in rural India: Caste and tribe. Review of Income and Wealth, 54(1): 50-70.

Gangopadhyay, S., and W. Wadhwa. 2004a. Changing pattern of household consumption expenditure.Down loadable from http://planningcommission.nic.in/reports/sereport /ser/sty sercphc.pdf.

Gangopadhyay, S., and W. Wadhwa. 2004b. Are Indian female-headed households more vulnerable to poverty. India Development Foundation, Gurgaon. Downloadable from

https://www.researchgate.net/profile/Shubhashis_Gangopadhyay/publication/238622873_Are Indian_female-

headed_households_more_vulnerable_to_poverty/links/563ff21c08ae8d65c015133c.pdf

Grootaert, C., and J. Braithwaite. 1998. Poverty correlates and indicator-based targeting in Eastern Europe and the former Soviet Union, Mimeo, Washington, DC: The World Bank. Downloadable from http://documents.worldbank.org/curated/ en/7056314687 58682526/ 120520322_20041117162549/additional/multi-page.pdf.

Ham, J.C., Svejnar, J., and K. Terrell. 1998. Unemployment and social safety net during transitions to a market economy: Evidence from the Czech and Slovak Republics. American Economic Review, 88(5): 1117-1142.

Heckman, J.J., Lochner, L.J., and P.E. Todd. 2006. Earnings Functions, Rates of Return and Treatment Effects: The Mincer Equation and Beyond. In Hanusheck, E.A., and Welch, F. (eds.) Handbook of the Economics of Education vol. 1), Elsevier.

Hulme, D., and A. Shepherd. 2003. Conceptualizing chronic poverty. World Development, 31(3): 403-423.

Klugman, J. 2002. A Sourcebook for Poverty Reduction Strategies, Volume 1, Washington, DC: The World Bank. Downloadable from http://documents.worldbank.org/curated/en/

156931468138883186/Core-techniques-and-cross-cutting-issues.

Neuman, S., and J.G. Silber. 1996. Wage discrimination across ethnic groups: Evidence from Israel. Economic Inquiry, 34(4): 648-661.

Oaxaca, R. 1973. Male-female wage differentials in urban labor markets. International Economic Review, 14(3): 693-709.

Rodriguez, A.G., and S.M. Smith. 1994. A comparison of determinants of urban, rural and farm poverty in Costa Rica. World Development, 22(3): 381-397. 
Sen, A.K. 1993. Capability and well-being. In Nussbaum, M. and Sen, A.K. eds. The Quality of Life, pp.30-53. Oxford University Press.

Sen, A.K. 2005. Human rights and capabilities. Journal of Human Development, 6(2): 151166.

Volkert, J. 2006. European Union poverty assessment: A capability perspective, Journal of Human Development, 7(3): 359-383.

Wood, G. 2003. Staying secure, staying poor: The "Faustian bargain". World Development, 31(3): 455-471.

World Bank. 2016. Poverty and Shared Prosperity 2016: Taking on Inequality. Washington, DC: World Bank. doi:10.1596/978-1-4648-0958-3.

Yun, M-S. 2004. Decomposing differences in the first moment. Economics Letters, 82(2): 275-280. 